\title{
KETENTUAN PIDANA TENTANG UJARAN KEBENCIAN DI INDONESIA
}

\author{
oleh \\ Joko Suroso
}

\begin{abstract}
ABSTRAK
Tulisan ini bertujuan untuk memaparkan mengenai ujaran kebencian dalam kerangka ketentuan pidana di Indonesia sehingga masyarakat dapat memahami dengan baik. Selain itu, tulisan ini juga berusaha untuk memberikan masukan mengenai pengaturan ketentuan mengenai ujaran kebencian secara jelas dalam peraturan perundangan di Indonesia sehingga mampu memberikan rasa kepastian hukum bagi seluruh warga negara. Penelitian ini mempergunakan metode yuridis normatif yaitu mempelajari bahan hukum sekunder dan tersier dan kemudian menganalisis dan menyimpulkannya. Ketentuan pidana mengenai ujaran kebencian memang telah diatur didalam KUHP dan peraturan perundang-undangan lainnya, namun ketentuan tersebut masih belum mampu menciptakan rasa kepastian hukum didalam masyarakat, terutama belum terdapat definisi ujaran kebencian, yang dibuktikan dengan pro kontra wacana yang masih berkembang didalam masyarakat.
\end{abstract}

Kata kunci: ujaran kebencian, ketentuan pidana

\section{PENDAHULUAN}

Seiring dengan perkembangannya, internet mampu melahirkan suatu jaringan baru guna memenuhi kebutuhan manusia dalam aspek informasi dan komunikasi. Salah satu jenis media baru yang kehadirannya sangat fenomenal di belahan dunia saat ini adalah media sosial. Menjadi fenomenal karena hadirnya media sosial membuat perubahan dalam segala aspek tatanan kehidupan manusia.Saat ini telah banyak sekali media sosial yang telah tersedia, seperti Facebook, Twitter, Path, Instagram, My Space, dan masih banyak lagi. Tingginya pengguna media sosial inimembuktikan bahwa pada dasarnya banyak sekali dampak ataupun manfaat yang disediakan, baik dari dampak positif maupun negatif.

Pesatnya perkembangan media sosial dikarenakan semua orang bisa menggunakannya tanpa memandang usia, baik anak kecil hingga orang tua bisa menggunakan media sosial. Media sosial tidak hanya dapat dinikmati oleh kalangan atas, namun kalangan bawah juga dapat menikmati kecanggihan dari media sosial karena penggunaannya sangat mudah dan mudah dijangkau untuk semua khalayak. Wilayah jangkauan media sosial sangatlah luas tidak hanya bisa berkomunikasi dalam negeri tetapi berbagi negeri pun bisa terjangkau. Komunikasi yang melebihi batas ini terkadang membuat pengguna keasikan bersosial media.

Pada umumnya, masyarakat menggunakan media sosial sebagai tempat untuk mencari informasi, menjalin komunikasi dengan banyak orang dan juga sebagai media untuk belajar, namun seiring berjalannya waktu dan kebebasan tanpa batas, penggunaan media sosial tidak hanya digunakan sebagai sarana untuk mendapatkan atau berbagi informasi yang bermanfaat, tetapi bagi para pengguna media sosial yang tidak bertanggung jawab media sosial bisa digunakan sebagai sarana untuk melakukan kejahatan di dunia maya.Kejahatan di dunia maya sangatlah banyak dan beragam jenisnya, seperti penipuan berkedok jual beli online, ujaran kebencian terhadap suatu golongan, pencemaran nama baik, prostitusi online, pornografi anak, menyebarkan berita bohong dan masih banyak lagi kejahatan yang lain yang dapat merugikan baik secara materil maupun non-materil bagi penggunanya. Sebagian besar permasalahan yang 
terjadi di media sosial diakibatkan karena kurangnya pemahaman dan kesadaran dari masyarakat dalam beretika saat menggunakan media sosial.

Melihat kondisi di atas diperlukan suatu perangkat aturan yang khusus mengatur tentang kejahatan komputer dan perlindungan hukum terhadap pemanfaatan teknologi informasi dan komunikasi agar dapat berkembang secara optimal. Oleh karena itu, pemerintah mengeluarkan Undang-undang Nomor 19 Tahun 2016 tentang Perubahan Atas Undang-undang Nomor 11 Tahun 2008 Tentang Informasi dan Transaksi Elektronik. Secara umum Undang-undang Nomor 19 Tahun 2016 tentang Informasi dan Transaksi Elektronik dapat dibagi dua bagian besar yaitu mengatur mengenai informasi dan transaksi elektronik dan mengatur perbuatan yang dilarang.Mengenai perbuatan yang dilarang dalam Undang-undang Informasi dan Transaksi Elektronik di atur dalam BAB VII yang terdiri dari 9 pasal.

Pasal 27 Undang-undang Nomor 19 Tahun 2016 tentang Informasi dan Transaksi Elektronik, BAB VII tentang Perbuatan Yang Dilarang, menyebutkan :

(1) Setiap Orang dengan sengaja dan tanpa hak mendistribusikan dan/atau mentransmisikan dan/atau membuat dapat diaksesnya Informasi Elektronik dan/atau Dokumen Elektronik yang memiliki muatan yang melanggar kesusilaan.

(2) Setiap Orang dengan sengaja dan tanpa hak mendistribusikan dan/atau mentransmisikan dan/atau membuat dapat diaksesnya Informasi Elektronik dan/atau Dokumen Elektronik yang memilik muatan perjudian.

(3) Setiap Orang dengan sengaja dan tanpa hak mendistribusikan dan/atau mentransmisikan dan/atau membuat dapat diaksesnya Informasi Elektronik dan/atau Dokumen Elektronik yang memilik muatan penghinaan dan/atau pencemaran nama baik.

(4) Setiap Orang dengan sengaja dan tanpa hak mendistribusikan dan/atau mentransmisikan dan/atau membuat dapat diaksesnya Informasi Elektronik dan/atau Dokumen Elektronik yang memilik muatan yang memiliki muatan pemerasan dan/atau pengancaman.

Dengan lahirnya undang-undang tersebut, seharusnya pengguna media sosial mempunyai cara yang cerdas agar media sosial digunakan sebagai mestinya dan tidak melanggar aturanaturan hukum yang berlaku. Namun pada kenyataannya meski sudah ada aturan hukum yang mengatur tentang kejahatan dunia maya pada pelaksanaannya masih adapengguna media sosial yang mengabaikan peraturan tersebut. Perkembangan yang sangat pesat dilihat dari banyaknya masyarakat yang menggunakan media sosial. Dengan banyaknya pengguna media sosial sehingga kemungkinan terjadinya kejahatan dalam dunia maya sangat besar. Kejahatan tersebut salah satunya adalah ujaran kebencian.

Ujaran kebencian telah cukup mendapat perhatian masyarakat dewasa ini. Perhatian masyarakat ini semakin berkembang dikarenakan banyaknya kasus-kasus ujaran kebencian yang mencuat dan menjadi diskusi di publik. Pro dan kontra mengenai pengaturan dan implementasi peraturan yang ada terkait ujaran kebencian pun berkembang. Sebagian besar kasus-kasus yang mencuat terkait dengan penggunaan internet dan media sosial. Perkembangan penggunaan internet dan media sosial tampaknya masih harus diimbangi dengan kecerdasan penggunanya, sehingga tidak terjerumus kedalam kasus pidana.

Pertanyaan yang muncul ketika membicarakan ujaran kebencian akan selalu dikaitkan dengan kemerdekaan dalam berekspresi yang dimiliki setiap individu. First Amandment of United States Constitution menyatakan bahwa: "Congress shall make no law . . abridging the 
freedom of speech."1 First Amandment of United States Constitution dengan jelas menyatakan bahwa tidak diperbolehkan adanya batasan terkait kemerdekaan berekspresi seseorang. Akan tetapi, kemerdekaan berekspresi masyarakat yang tidak dibatasi akan menimbulkan tindakantindakan yang dapat memicu kekerasan dan amarah karena ucapan-ucapan kebencian yang ditujukan kepada pihak-pihak tertentu. ${ }^{2}$

Negara Kesatuan Republik Indonesia hingga sekarang belum memiliki definisi yang jelas dan lengkap terkait hate speech atau yang disebut juga dengan ujaran kebencian. Beberapa regulasi yang dimiliki Indonesia mengatur terkait ujaran kebencian secara laten, diantaranya adalah Kitab Undang-undang Hukum Pidana, Undang-undang Hak Asasi Manusia dan Undangundang Informasi dan Transaksi Elektronik. Undang-Undang Nomor 11 Tahun 2008 tentang Informasi dan Transaksi Elektronik merupakan bentuk konkrit bahwa Indonesia sebagai suatu Negara telah memahami kepentingan membuat suatu aturan yang dapat menciptakan kenyamanan pengguna media sosial dalam beraktivitas melalui media elektronik. Namun, dengan diterbitkannya Undang-undang ITE menimbulkan perdebatan mengenai kemerdekaan berekspresi yang merupakan salah satu hak asasi manusia. Merupakan suatu hal penting untuk diketahui oleh masyarakat mengenai hubungan antara Undang-undang ITE dengan hak atas kemerdekaan berekspresi yang dimiliki setiap individu.

Beberapa kasus terkait ujaran kebencian tersebut adalah sebagai berikut: ${ }^{3}$

1. Pada tahun 2014, Florence Sihombing, 26 tahun, mahasiswa pascasarjana Universitas Gadjah Mada (UGM), ditahan setelah berstatus tersangka karena dianggap telah menghina warga Yogyakarta. Kasus ini berawal dari unggahan tulisan Florence diakun media sosialnya yang kemudian dianggap sebagai hinaan bagi warga Yogyakarta. Florence mendapatkan reaksi keras dari pengguna media sosial lainnya, dan kemudian dilaporkan oleh salah satu Lembaga Swadaya Masyarakat ke Polisi. Florence kemudian ditahan pada 30 Agustus 2014 dan dijerat dengan Pasal 27 ayat (3) jo Pasal 45 ayat (1), Pasal 28 ayat (2) jo Pasal 45 ayat (2) Undangundang Nomor 11 Tahun 2008 tentang Informasi dan Transaksi Elektronik (UU ITE). Selain itu, dia juga dijerat dengan Pasal 310 dan/atau Pasal 311 Kitab Undang-undang Hukum Pidana (KUHP). Saat ini Flores sudah bebas setelah mengajukan penangguhan penahanan.

2. Pada tahun 2015, seorang perempuan berinisial ISW, 24 tahun, di Ponorogo, Jawa Timur menjadi tersangka karena mengunggah meme yang dianggap menghina Polisi. ISW dilaporkan oleh anggota Satuan Lalu Lintas Polres Ponorogo, Bripda Aris Kurniawan yang tidak terima fotonya dijadikan meme di halaman media sosial milik ISW. Meme tersebut memperlihatkan foto Bripda Aris yang sedang bertugas dan diberi tulisan yang seakan-akan menuduhnya melakukan sesuatu yang negatif. ISW dijerat dengan Pasal 32 ayat (1) UU ITE.

3. Pada tahun 2016, Pelajar kelas II Sekolah Menengah Kejuruan (SMK) Negeri Soppeng, Sulawesi Selatan, berinisial SRS, 18 tahun, digelandang ke Markas Kepolisian Resor setempat karena dianggap menghina institusi kepolisian melalui komentarnya disebuah grup media sosial. Setelah diperiksa, SRS diperbolehkan pulang dan tindak mengalami penahanan, namun wajib lapor hingga proses penyelidikan selesai. SRS sendiri tidak menyangka bahwa komentarnya di media sosial dapat menyebabkan dirinya berurusan dengan polisi.

\footnotetext{
${ }^{1}$ United States, First Amandment of United States Constitution.

${ }^{2}$ Yulia A. Timofeeva, "Hate Speech Online: Restricted or Protected? Comparison of Regulations In The United States and Germany”, Journal Transnational \& Policy Vol. 12:2 (Spring, 2003), hlm. 270

3 http://koran-sindo.com/page/news/2017-12-09/0/2/4 Kasus Hate Speech Di Indonesia, diakses pada 19 Mei 2018 pukul 15.54
} 
4. Pada tahun 2017, Muhammad Faisal Tanong, 44 tahun, di Perumahan Kompleks Pertamina, Koja, Jakarta Utara, ditangkap Bareskrim karena dianggap menyebarkan ujaran kebencian terhadap Presiden Joko Widodo, Kapolri Jenderal Tito Karnavian, partai dan ormas. Muhammad Faisal Tanong ditangkap karena mengedit foto-foto yang diambil dari internet dengan menggunakan aplikasi dengan konten SARA kemudian diunggah ke akun media sosialnya.

Dari beberapa kasus diatas, dapat diperhatikan bahwa tidak semua pelaku memiliki pemahaman bahwa tindakannya merupakan bagian dari ujaran kebencian, meskipun ada juga pelaku yang dengan sengaja mempersiapkan konten ujaran kebencian untuk diunggah dimedia sosialnya.

Selain kasus-kasus tersebut diatas, terdapat kasus-kasus ujaran kebencian yang pekat dengan nuansa politik. Sebut saja kasus Buni Yani dan Basuki Tjahja Purnama alias Ahok. Kasus-kasus yang melibatkan nama-nama besar politisi, artis dan aktivis gerakan Hak Asasi Manusia. Tentu saja semua kasus ini semakin menambah perhatian masyarakat terhadap ujaran kebencian dan kasus ujaran kebencian yang berkembang. Oleh sebab itu, penting untuk membahas kembali ketentuan mengenai ujaran kebencian yang telah ada pada saat ini, untuk bisa dipahami oleh masyarakat luas sehingga masyarakat semakin cerdas dalam memahami tindak pidana ujaran kebencian. Pemahaman mengenai tindak pidana ujaran kebencian ini sangat penting dalam usaha menciptakan suasana masyarakat yang damai.

Selain itu, perkembangan hukum untuk kemudian membuat ketentuan yang lebih jelas dan gamblang mengenai ujaran kebencian yang seimbang dan menjamin terlaksananya hak dasar rakyat atas kebebasan berpendapat dan berekspresi, sudah mulai dapat didiskusikan, mengingat saat ini belum ada ketentuan hukum yang jelas tentang ujaran kebencian dalam peraturan perundang-undangan yang ada.

\section{PEMBAHASAN}

Ujaran kebencian merupakan suatu masalah yang tidak hanya dihadapi di Indonesia, melainkan merupakan sebuah masalah internasional. Permasalahan timbul ketika aturan yang berlaku bersinggungan dengan hak asasi manusia, yakni kemerdekaan berekspresi. Hingga sekarang, terdapat beberapa aturan baik internasional maupun nasional yang memberikan jaminan atas hak kemerdekaan berekspresi, namun di lain sisi aturan tersebut juga mengandung batasan ataupun limitasi bagi setiap manusia dalam melangsungkan hak atas kemerdekaan berekspresi. Deklarasi Universal Hak-hak Asasi Manusia (DUHAM) mengatur mengenai hal ini dalam pasal 19 dan pasal 29 ayat (2). ${ }^{4}$ Salah satu traktat internasional lain yang mengatur mengenai kemerdekaan berekspresi dan batasannya adalah Konvenan Internasional Hak-hak Sipil dan Politik (ICCPR). Pasal 19 dan pasal 20 ayat (2) dari ICCPR mengandung mengenai jaminan dan batasan bagi setiap individu dalam melangsungkan hak mereka dalam berekspresi. ${ }^{5}$

Selain traktat-traktat internasional, Undang-Undang Dasar 1945 Amandemen Keempat juga mengatur mengenai hak atas kemerdekaan berekspresi dan batasan-batasan yang harus dipatuhi, yakni dalam pasal $28 \mathrm{E}$ ayat (2), pasal $28 \mathrm{~F}$ dan pasal $28 \mathrm{~J}$ ayat (2). Undang-Undang Nomor 39 Tahun 1999 tentang Hak Asasi Manusia juga mengatur mengenai kemerdekaan berekspresi yang tertera dalam pasal 14 ayat (2). Sejak 2008, Indonesia memiliki undang-undang

\footnotetext{
${ }^{4}$ United Nations, Universal Declaration of Human Rights, 1948, Article 19 and Article 29(2).

${ }^{5}$ United States, International Covenant on Civil and Political Rights, 1976, Article 19 and Article 20(2).
} 
yang secara spesifik membahas mengatur mengenai informasi dan transaksi elektronik yaitu Undang-Undang No. 11 Tahun 2008 tentang Informasi dan Transaksi Elektronik. Undangundang tersebut memberikan larangan, batasan serta pengaturan sanksi pidana bagi individu yang melanggar aturan-aturan yang terkandung di dalamnya, khususnya terkait ujaran kebencian online yang tertera dalam pasal 27 ayat (3), pasal 28 ayat (2) dan pasal 29 ITE.

Berbagai instrumen HAM mengatur batasan-batasan atas hak-hak tertentu. Namun, suatu pembatasan dapat dinyatakan tidak sah atau merupakan pelanggaran apabila tidak didasarkan kepada syarat-syarat pembatasan yang sah dan sesuai. Disamping itu, kita juga mengenal adanya konsep bahwa negara dapat menggunakan "margin of appreciation" yang maksudnya adalah negara dapat dimintakan pertanggungjawaban nasionalnya dalam rangka memenuhi kewajiban mereka dalam hal HAM. ${ }^{6}$ Akan tetapi, sering dengan adanya jaminan hak atas kemerdekaan berekspresi, batasan akan mengikuti hak tersebut. ${ }^{7}$

Tanya Cohen, seorang penulis dan aktivis HAM terutama mengenai peristiwa hate speech membagi empat macam kategori ungkapan yang dapat dikatakan hate speech:

"(1) targeted vilification, (2) diffuse vilification, (3) organized political advocacy for exclusionary and/or eliminationist policies, and (4) other assertions of fact or value which constitute an adverse judgment on an identifiable raial or religious group." 8

Fitnah kepada individu tertentu menurut Tanya Cohen sudah termasuk dalam kategori hate speech, begitu juga apabila tindakan fitnah tersebut diarahkan kepada kelompok atau kumpulan individu tertentu secara menyebar. Advokasi politik untuk mengekslusifkan kelompok tertentu atau dalam artian menciptakan aturan yang mengasingkan individu atau kelompok tertentu, dan juga pernyataan yang menghakimi ras tau kelompok agama tertentu.

Tertanggal 8 November 2015, terjadi perubahan baru mengenai pengertian ujaran kebencian yang disampaikan oleh Kapolri Jenderal Polisi Badrodin Haiti berdasarkan Surat Edaran Kepala Polri Nomor 06/X/2015 yang diterbitkannya tentang Penanganan Ujaran Kebencian. ${ }^{9}$ Dalam Surat Edaran tersebut, dapat kita pahami bahwa ujaran kebencian adalah tindakan yang dapat berupa tindak pidana yang diatur dalam KUHP dan ketentuan pidana lainnya di luar KUHP, yang berbentuk antara lain: (1) Penghinaan; (2) Pencemaran nama baik; (3) Penistaan; (4) Perbuatan tidak menyenangkan; (5) Memprovokasi; (6) Menghasut; (7) Penyebaran berita bohong dan semua tindakan di atas memiliki tujuan atau bisa berdampak pada tindak diskriminasi, kekerasan, penghilangan nyawa, dan/atau konflik sosial.

Ujaran kebencian sebagaimana dimaksud di atas, bertujuan untuk menghasut dan menyulut kebencian terhadap individu dan/atau kelompok masyarakat dalam berbagai komunitas yang dibedakan dari aspek: (1) Suku; (2) Agama; (3) Aliran keagamaan; (4) Keyakinan/kepercayaan; (5) Ras; (6) Antar golongan; (7) Warna kulit; (8) Etnis; (9) Gender; (10) Kaum diffabel (cacat); (11) Orientasi seksual. Bahwa ujaran kebencian (hate speech) dapat

\footnotetext{
${ }^{6}$ Steven Greer, The Margin of Appreciation: Interpretation and Discretion Under The European Convention On Human Rights, Council of Europe, United Kingdom, 2000, hlm. 5.

${ }^{7}$ ELSAM, Buku Saku Kebebasan Berekspresi di Internet, Lembaga Studi dan Advokasi Masyarakat [ELSAM], Jakarta, 2013, hlm. 34-35.

${ }^{8}$ Caleb Yong, Does Freedom of Speech Include Hate Speech, Springer Science+ Business Media B.V, USA, 2011, hlm. 386.

9 Ruli, Surat Edaran Kapolri "Ujaran Kebencian" Dinilai Suatu Kemajuan" Dinilai Suatu Kemajuan, http://nasional.harianterbit.com /nasional/2015/10/29/45932//25/Surat-Edaran-Kapolri-Ujaran-Kebencian-Dinilai Suatu-Kemajuan, diunduh 23 Januari 2018.
} 
dilakukan di berbagai media, antara lain: (1) Dalam orasi kegiatan kampanye; (2) Spanduk atau banner; (3) Jejaring media sosial; (4) Penyampaian pendapat di muka umum (demonstrasi); (5) Ceramah keagamaan; (6) Media masa cetak maupun elektronik; (7) Pamflet.

Keberadaan Surat Edaran dari Kapolri ini menandakan bahwa kesadaran dari aparatur Negara terkait hate speech atau ujaran kebencian sudah mulai masuk pada tahap layak dan patut mendapat perhatian lebih dan segera ditangani. Peningkatan kepedulian terhadap hak asasi manusia juga menjadi salah satu tolak ukur atas peristiwa ujaran kebencian ini. Masalah ujaran kebencian ini dianggap perlu untuk diatasi guna merongrong prinsip berbangsa dan bernegara Indonesia yang berbhineka tunggal ika serta melindungi keragaman kelompok dalam bangsa Indonesia, maka dari itu personel Polri selaku aparat Negara yang memiliki tugas memelihara keamanan dan ketertiban masyarakat, penegakan hukum serta perlindungan dan pelayanan masyarakat, sehingga dapat diambil tindakan pencegahan sedini mungkin sebelum timbulnya tindak pidana sebagai akibat dari ujaran kebencian.

Menurut Surat Edaran Kepala Kepolisian Negara Republik Indonesia Nomor SE/6/X/2015 tentang Penanganan Ujaran Kebencian tertanggal 8 Oktober 2015, penegakan hukum atas dugaan terjadinya tindak pidana ujaran kebencian mengacu pada ketentuan: ${ }^{10}$

1. Pasal 156 KUHP, yang berbunyi:

"barang siapa didepan umum menyatakan perasaan permusuhan, kebencian atau merendahkan terhadap satu atau lebih suku bangsa Indonesia dihukum dengan hukuman penjara selama-lamanya empat tahun dengan hukuman denda setinggi-tingginya empat ribu lima ratus rupiah"

2. Pasal 157 KUHP, yang berbunyi:

“(1) barang siapa menyiarkan, mempertunjukkan atau menempelkan tulisan atau lukisan dimuka umum, yang isinya mengandung pernyataan perasaan permusuhan, kebencian atau penghinaan diantara atau terhadap golongan-golongan rakyat Indonesia, dengan maksud supaya isinya diketahui atau lebih diketahui oleh umum, diancam dengan pidana penjara paling lama dua tahun enam bulan atau pidana denda paling banyak empat ribu lima ratus rupiah.

(2) jika yang bersalah melakukan kejahatan tersebut pada waktu menjalankan pencariannya dan pada saat itu belum lewat lima tahun sejak pemidanaannya menjadi tetap karena kejahatan semacam itu juga, yang bersangkutan dapat dilarang menjalankan pencarian tersebut"

3. Pasal 310 KUHP, yang berbunyi:

"(1) barang siapa dengan sengaja menyerang kehormatan atau nama baik seseorang dengan menuduhkan sesuatu hal, yang maksudnya terang supaya hal itu diketahui umum, diancam karena pencemaran dengan pidana penjara paling lama Sembilan bulan atau pidana denda paling banyak empat ribu lima ratus rupiah.

(2) jika hal itu dilakukan dengan tulisan atau gambaran yang disiarkan, dipertunjukkan atau ditempelkan dimuka umum, maka diancam karena pencemaran tertulis dengan pidana penjara paling lama satu tahun empat bulan atau pidana denda paling banyak empat ribu lima ratus rupiah.

(3) tidak merupakan pencemaran atau pencemaran tertulis, jika perbuatan jelas dilakukan demi kepentingan umum atau karena terpaksa untuk membela diri”

4. Pasal 311 KUHP, yang berbunyi:

${ }^{10}$ Anam, M. Chairul dan Muhammad Hafiz, "SE Kapolri Tentang Penanganan Ujaran Kebencian (Hate Speech) dalam kerangka Hak Asasi Manusia” Jurnal Keamanan Nasional, Vol. 1 No. 3, 2015. 
“(1) jika yang melakukan kejahatan pencemaran atau pencemaran tertulis dibolehkan untuk membuktikan apa yang dituduhkan itu benar, tidak membuktikannya, dan tuduhan dilakukan bertentangan dengan apa yang diketahui, maka dia diancam melakukan fitnah dengan pidana penjara paling lama empat tahun.

(2) pencabutan hak-hak berdasarkan Pasal 35 No. 1-3 dapat dijatuhkan"

5. Pasal 28 Jis Pasal 45 ayat (2) UU ITE, yang berbunyi:

Pasal 28:

“(1) setiap orang dengan sengaja dan tanpa hak menyebarkan berita bohong dan menyesatkan yang mengakibatkan kerugian konsumen dalam Transaksi Elektronik.

(2) setiap orang dengan sengaja dan tanpa hak menyebarkan informasi yang ditujukan untuk menimbulkan rasa kebencian atau permusuhan individu dan/atau kelompok masyarakat tertentu berdasarkan atas suku, agama, ras dan antar golongan (SARA)."

Pasal 45 ayat (2)

“(2) setiap orang yang memenuhi unsur sebagaimana dimaksud dalam Pasal 28 ayat (1) atau ayat (2) dipidana dengan pidana penjara paling lama 6 (enam) tahun dan/atau denda paling banyak Rp. 1.000.000.000,00 (satu miliar rupiah)

6. Pasal 16 UU No. 40 Tahun 2008 Tentang Penghapusan Diskriminasi Ras dan Etnis, yang berbunyi:

"setiap orang yang dengan sengaja menunjukkan kebencian atau rasa benci kepada orang lain berdasarkan diskriminasi ras dan etnis sebagaimana dimaksud dalam Pasal 4 huruf $b$ angka 1, angka 2, atau angka 3, dipidana dengan pidana penjara paling lama 5 (lima) tahun dan/atau denda paling banyak Rp. 500.000.000,00 (lima ratus juta rupiah)."

Meskipun surat edaran tersebut merupakan panduan bagi internal kepolisian, namun beberapa informasi tetaplah dapat diperhatikan oleh masyarakat, seperti ketentuan yang dijadikan acuan dalam melakukan penegakan hukum tersebut diatas.

Simons menyatakan tindak pidana adalah tindakan melawan hukum yang telah dilakukan dengan sengaja ataupun dengan tidak sengaja oleh seseorang yang dapat dipertanggungjawabkan atas tindakannya, oleh undang-undang telah dinyatakan sebagai tindakan yang dapat dihukum. ${ }^{11}$

Melihat penjelasan yang disampaikan oleh Simons, ketentuan-ketentuan yang menjadi acuan dalam penegakan hukum ketika terjadi dugaan tindak pidana ujaran kebencian sebagaimana disebutkan diatas, telah memenuhi pengaturan yang diperlukan, yaitu terdapat larangan atas suatu tindakan tertentu, yang apabila dilakukan akan mendapatkan hukuman. Sementara, pelaku yang melakukan tindakan yang dilarang tersebut haruslah dapat dimintai pertanggungjawabannya, atau dengan kata lain telah cakap secara hukum.

Apabila diperhatikan, ketentuan yang menjadi acuan penegakan hukum atas dugaan terjadinya ujaran kebencian sebagaimana disebutkan diatas, belum secara gamblang mengatur mengenai tujuan ataupun dampak dari tindakan ujaran kebencian tersebut. Tentu saja, terdapat unsur-unsur yang harus dipenuhi sehingga suatu perbuatan dikatakan sebagai suatu tindak pidana. Unsur-unsur dari tindak pidana ini haruslah dapat dibuktikan sehinga seseorang dapat dinyatakan telah melakukan tindak pidana dan harus menerima hukuman yang diancamkan.

Unsur-unsur tindak pidana ujaran kebencian, berdasarkan ketentuan-ketentuan diatas dapat dilihat berdasarkan:

1. Unsur Subyektif

a. Kesengajaan atau kealpaan (dolus atau culpa)

${ }^{11}$ Evi Hartanti, Tindak Pidana Korupsi Edisi Ke Dua, Sinar Grafika, Jakarta, 2008, hlm. 5 
Apakah suatu perbuatan yang dilarang tersebut dilakukan secara sengaja atau karena kelalaian.

b. Maksud pada suatu percobaan seperti yang termuat dalam Pasal 53 ayat (1) KUHP

Apakah perbuatan yang dilarang tersebut dilakukan untuk mencapai suatu tujuan tertentu, dalam hal ini berdampak pada tindak diskriminasi, kekerasan, penghilangan nyawa dan/atau konflik sosial.

c. Terencana seperti yang termuat dalam Pasal 340 KUHP Apakah perbuatan yang dilarang tersebut sudah direncanakan sebelumnya

d. Perasaan takut seperti yang termuat dalam Pasal 308 KUHP

Apakah terdapat rasa takut bahwa perbuatannya akan diketahui oleh orang lain sehingga berusaha untuk menutupi perbuatan yang dilakukannya.

2. Unsur obyektif

a. Sifat melawan hukum

Apakah perbuatan yang dilakukan adalah perbuatan melawan hukum yang telah jelas ketentuan dan ancaman pidananya.

b. Kualitas dari pelaku

Apakah pelaku merupakan berada pada posisi mampu mempengaruhi orang banyak dengan perbuatan yang dilakukannya

C. Kausalitas, yaitu hubungan antara suatu tindakan sebagai penyebab dengan kenyataan sebagai akibat. ${ }^{12}$

Dalam peraturan perundangan Indonesia, dapat dikatakan bahwa tidak terdapat rumusan ketentuan yang tegas mengenai tindak pidana ujaran kebencian. Sebagaimana yang telah dibahas diatas, ketentuan mengenai ujaran kebencian yang ada terdapat pada beberapa peraturan perundang-undangan dan belum disatukan pada satu ketentuan yang baku. Menarik untuk memperhatikan isi dari Surat Edaran Kapolri tentang Penanganan Ujaran Kebencian yang menyatakan bahwa ujaran kebencian dapat berupa tindak pidana yang diatur dalam KUHP dan ketentuan pidana lainnya diluar KUHP, yang berbentuk antara lain: penghinaan, pencemaran nama baik, penistaan, perbuatan tidak menyenangkan, memprovokasi, menghasut, penyebaran berita bohong dan semua tindakan tersebut memiliki tujuan atau bisa berdampak pada tindak diskriminasi, kekerasan, penghilangan nyawa dan/atau konflik sosial. Lebih lanjut, Surat Edaran tersebut juga menyatakan bahwa ujaran kebencian sebagaimana yang telah disebutkan, bertujuan untuk menghasut dan menyulut kebencian terhadap individu dan/atau kelompok masyarakat dalam berbagai komunitas yang dibedakan dari aspek suku, agama, aliran keagamaan, keyakinan/kepercayaan, ras, antargolongan, warna kulit, etnis, gender, kaum difabel dan orientasi seksual. Kemudian, juga dijelaskan dalam Surat Edaran tersebut bahwa ujaran kebencian dapat dilakukan melalui berbagai media, antara lain dalam orasi kegiatan kampanye, spanduk atau banner, jejaring media sosial, penyampaian pendapat dimuka umum (demonstrasi), ceramah keagamaan, media massa cetak maupun elektronik dan pamflet.

Rumusan tersebut diatas memberikan pengertian tentang tindak pidana ujaran kebencian sebagai tindak pidana dalam bentuk antara lain penghinaan, pencemaran nama baik, penistaan, perbuatan tidak menyenangkan, memprovokasi, menghasut, penyebaran berita bohong yang bertujuan untuk menyulut kebencian terhadap individu dan/atau kelompok masyarakat dalam berbagai komunitas yang dibedakan dari aspek suku, agama, aliran keagamaan,

\footnotetext{
12 Ibid., hlm. 7
} 
keyakinan/kepercayaan, ras, antargolongan, warna kulit, etnis, gender, kaum difabel dan orientasi seksual, yang dilakukan melalui berbagai media, antara lain dalam orasi kegiatan kampanye, spanduk atau banner, jejaring media sosial, penyampaian pendapat dimuka umum (demonstrasi), ceramah keagamaan, media massa cetak maupun elektronik dan pamflet, yang bisa berdampak pada tindak diskriminasi, kekerasan, penghilangann nyawa dan/atau konflik sosial.

Rumusan yang seperti diatas, belum ditemukan dalam peraturan perundang-undangan di Indonesia. Dapat diketahui, berdasarkan pembahasan diatas, bahwa ketentuan-ketentuan mengenai ujaran kebencian yang ditemukan dalam KUHP Pasal 156, 157, 310, 311, Pasal 28 jis Pasal 45 ayat (2) UU ITE dan Pasal 16 UU No. 40 Tahun 2008 tentang Penghapusan Diskriminasi Ras dan Etnis masing-masing mengatur mengenai tindakan yang berbeda-beda. Sedangkan dalam Undang-Undang Nomor 1 Tahun 1946 tentang Peraturan Hukum Pidana, khususnya Pasal 14 dan 15 yang dijadikan sebagai rujukan sanksi dari pelanggaran Undang-undang ITE. Dan sepertinya Pemerintah juga belum secara serius mensosialisasikan kedua UU tersebut dan belum secara tegas menjatuhkan sanksi kepada setiap pihak yang melanggar UU tersebut.

Ketentuan yang diatur dalam UU No.1 Tahun 1946, sangat longgar karena tidak memuat unsur kesengajaan. Akibatnya bisa berdampak buruk terhadap kebebasan berekspresi. Selaras itu yang penting dilakukan aparat yakni menyeimbangkan upaya penegakan hukum yang dilakukan dengan kebebasan berekspresi. Delik yang diatur pasal 14 dan 15 UU No.1 Tahun 1946 sifatnya formil yakni harus ada akibatnya. Polisi bisa memproses kasus ini tanpa adanya laporan dari masyarakat.

Hal tersebut dapat dilihat dari betapa masih merajalelanya pengguna media sosial membuat dan membagikan/menyebarkan berita bohong dan ujaran kebencian, khususnya di facebook dengan caption: "Tolong bantu sebarkan agar orangnya cepat tertangkap". Mereka sama sekali tidak merasa bersalah dan telah melakukan pelanggaran UU ITE dan seakan-akan tidak takut dengan sanksi pidana akibat dari perbuatannya tersebut. Bahkan sebaliknya mereka justru telah merasa berjasa membantu pemerintah, dalam hal ini pihak yang kepolisian, untuk mendapatkan informasi agar lebih cepat menciduk pelaku.

Berdasarkan uraian di atas, dapat kita lihat bahwa jenis pidana yang dapat diberikan terkait peristiwa ujaran kebencian online dalam KUHP ada yang hanya dapat berupa pidana penjara atau pidana denda (pasal $310 \mathrm{KUHP}$ dan pasal $157 \mathrm{KUHP}$ ), sedangkan pasal 156a dan pasal 369 KUHP hanya pidana penjara saja. Akan tetapi, dalam UU ITE, ketentuan pidana yang dapat dikenakan pada pelaku hanya terdiri dari dua macam jenis, yakni pidana penjara dan pidana denda sesuai dengan keputusan Hakim. Kita dapat juga melihat bahwa sanksi pidana yang diberikan jauh lebih berat dalam UU ITE dibandingkan dengan KUHP.

Mahkamah Konstitusi pernah menyatakan bahwa wajar adanya perbedaan sanksi antara ke dua aturan perundang-undangan tersebut. Mahkamah Konstitusi mengatakan bahwa salah satu perbedaan antara komunikasi di dunia nyata dengan dunia maya adalah media yang digunakan, sehingga setiap komunikasi dan aktivitas melalui internet akan memiliki dampak bagi kehidupan manusia dalam dunia nyata, misalnya melalui transfer data, melalui distribusi dan/atau transmisi dan/atau dapat diaksesnya informasi dan dokumentasi elektronik juga dapat menimbulkan dampak negatif yang sangat ekstrem dan masif di dunia nyata. Oleh karena itu, meskipun berat ringannya sanksi adalah wewenang pembentuk undang- undang, namun menurut Mahkamah, konsep pemidanaan dalam UU ITE merupakan delik yang dikualifikasi sebagai penghinaan atau pencemaran nama baik sehingga konsepnya akan mengacu kepada KUHP 
namun ancaman pidananya lebih berat. Perbedaan ancaman pidana antara KUHP dengan UU ITE adalah wajar karena distribusi dan penyebaran informasi melalui media elektronik relatif lebih cepat, berjangkauan luas, dan memiliki dampak yang masif.

Penulis setuju dengan diberlakukannya sanksi yang lebih keras di dalam UU ITE, hal ini dikarenakan Penulis merasa bahwa masalah ujaran kebencian sudah masuk ke dalam tahap dimana Pemerintah harus turun tangan lebih lanjut lagi dan terus mengembangkan UU ITE. Setiap manusia memiliki pendapat, dan merupakan kemerdekaan mereka untuk berpendapat baik secara lisan maupun dalam bentuk tulisan. Media sosial menjadi wadah yang tepat dalam keberlangsungan kemerdekaan berekspresi manusia, akan tetapi manusia yang merasa bahwa dunia maya merupakan dunia yang tidak nyata menyebabkan mereka berpikiran bahwa dunia di dalam media yang mereka miliki bukanlah dunia nyata. Akan tetapi, dunia yang ada di dalam media elektronik adalah dunia nyata. Tindakan yang dilakukan seseorang akan melalui media elektronik merupakan tindakan nyata dan dapat dimintakan pertanggungjawaban, begitu pula dengan pendapat-pendapat yang dikemukakan, tentu dapat dimintakan pertanggungjawaban, oleh karena itu pendapat yang dikemukakan haruslah dalam kadar dan batasan tertentu, disini masuklah fungsi UU ITE sebagai undang-undang khusus yang mengatur perilaku pengguna media sosial dalam melangsungkan kemerdekaan berekspresi mereka.

Dalam UU ITE, tidak didefinisikan apa yang termasuk ke dalam kategori ujaran kebencian. Surat Edaran Kapolri sudah mulai menginisiasikan gerakan baru dalam konteks ujaran kebencian tersebut, namun dikarenakan Surat Edaran tersebut berfungsi ke dalam atau secara internal, maka Surat Edaran hanya dapat digunakan sebagai acuan saja dan tidak dapat dijadikan dasar atas suatu kasus yang terjadi. UU ITE harus peka akan perkembangan teknologi di era sekarang ini, karena masalah-masalah yang timbul di masyarakat akan terus berubah dan UU ITE harus beradaptasi dengan baik agar dapat mengakomodasi kebutuhan masyarakat itu sendiri.

Ditengah pro dan kontra tindak pidana ujaran kebencian akibat kasus ujaran kebencian yang terus berkembang, serta atas nama perlindungan terhadap kebebasan berpendapat dan berekspresi, terdapat urgensi perumusan ketentuan mengenai tindak pidana ujaran kebencian yang komprehensif dan holistik, yang mampu memberikan rasa kepastian hukum dan kedamaian didalam masyarakat.

\section{PENUTUP}

\section{Kesimpulan}

Berdasarkan pembahasan diatas, maka dapat ditarik kesimpulan sebagai berikut:

1. Ketentuan mengenai ujaran kebencian di Indonesia yang ada pada saat ini, sebagaimana termaktub pada Pasal 156, 157, 310, 311 KUHP, Pasal 28 jis Pasal 45 ayat (2) UU ITE, dan Pasal 16 UU Nomor 40 Tahun 2008 tentang Penghapusan Diskriminasi Ras dan Etnis, telah jelas mengatur mengenai perbuatan yang dilarang dan ancaman pidananya, walaupun belum secara jelas mengatur mengenai dampak atau akibat dari perbuatan yang dilarang sebagai bagian dari ketentuan tindak pidana, namun belum ditemukan rumusan ketentuan tindak pidana ujaran kebencian yang komprehensif didalam peraturan perundang-undangan di Indonesia.

2. Kemerdekaan berekspresi merupakan hak asasi manusia, dan merupakan kewajiban dari suatu negara untuk memberikan jaminan bagi warga negaranya untuk melangsungkan hak yang dimilikinya tanpa terkecuali. Indonesia sebagai Negara yang berdaulat, telah memberikan 
perlindungan kepada masyarakat Indonesia, khususnya dalam hal kemerdekaan berekspresi. Hal ini dapat dilihat dari telah diratifikasinya beberapa instrumen hak asasi manusia internasional dan di implementasikan di hukum nasional seperti Universal Declaration of Human Rights dan International Covenant on Civil and Political Rights, selain itu, Indonesia juga telah membuat inovasi dengan dibentuknya Undang-undang Informasi dan Transaksi Elektronik sebagai hukum positif di Indonesia yang salah satunya mengatur mengenai kemerdekaan berekspresi, serta diterbitkannya Surat Edaran Kapolri Nomor: SE/06/X/2015 tentang Penanganan Ujaran Kebencian. Akan tetapi, selain sebagai jaminan bagi setiap individu untuk melangsungkan haknya, terutama dalam melangsungkan hak atas kemerdekaan berekspresi, keberadaan aturan-aturan tersebut menjadi penanda bahwa terdapat batasan-batasan yang tidak boleh dilanggar oleh setiap individu dalam melangsungkan haknya. Pasal 19 ayat (3) Kovenan Hak-hak Sipil dan Politik menyatakan bahwa dalam melangsungkan hak atas kemerdekaan berekspresi, setiap individu wajib untuk mengemban tangung jawab khusus, diantaranya adalah untuk menghormati hak atau nama baik orang lain, melidungi keamanan nasional atau ketertiban umum atau kesehatan atau moral umum. Pasal 29 ayat (2) Deklarasi Universal Hak Asasi Manusia juga menyatakan bahwa pembatasan yang dilakukan adalah semata-mata untuk menjamin pengakuan serta penghormatan terhadap hakhak dan kebebasan orang lain, dan untuk memenuhi syarat -syarat yang adil dalam hal moralitas, ketertiban dan kesejahteraan umum dalam suatu masyarakat yang demokratis. Hal ini juga berkaitan langsung dengan Undang-undang Dasar Republik Indonesia Amandemen Keempat, bahwa dalam Pasal 28F dinyatakan bahwa setiap orang berhak untuk memperoleh, mengolah dan menyampaikan informasi dengan menggunakan segala jenis saluran yang tersedia baginya. Kemudian diikuti oleh Pasal 28J ayat (2) yang menyatakan bahwa dalam menjalankan hak dan kebebasan, setiap orang harus menghormati hak dan kebebasan orang lain, sesuai dengan moral, nilai-nilai agama, keamanan dan ketertiban umum.

\section{Saran}

Saran yang dapat Penulis sampaikan adalah: Perkembangan hukum nasional Indonesia dalam mengatur kemerdekaan berekspresi khususnya dalam peristiwa ujaran kebencian online telah mengalami perubahan yang pesat, akan tetapi terdapat beberapa faktor penting yang masih dapat dikembangkan untuk tercapainya keadilan dan ketertiban di masyarakat Indonesia. Merupakan suatu kepentingan bagi Indonesia untuk membuat pendefinisian dari kata ujaran kebencian, hal ini dikarenakan tidak adanya definisi atau artian yang tersurat secara nyata dalam hukum yang berlaku di Indonesia sehingga menyebabkan ketidakpastian bagi para penegak hukum untuk menangani suatu kasus mengenai ujaran kebencian tersebut. Dengan dibentuknya pendifinisian ujaran kebencian, maka akan terdapat kepastian hukum dan kejelasan kinerja aparat hukum dalam menangani kasus-kasus ujaran kebencian dan ujaran kebencian online.

\section{DAFTAR PUSTAKA}

Anam, M. Chairul dan Muhammad Hafiz, "SE Kapolri Tentang Penanganan Ujaran Kebencian (Hate Speech) dalam kerangka Hak Asasi Manusia” Jurnal Keamanan Nasional, Vol. 1 No. 3, 2015.

Caleb Yong, Does Freedom of Speech Include Hate Speech, Springer Science+ Business Media B.V, USA, 2011 
ELSAM, Buku Saku Kebebasan Berekspresi di Internet, Lembaga Studi dan Advokasi Masyarakat [ELSAM], Jakarta, 2013

Evi Hartanti, Tindak Pidana Korupsi Edisi Ke Dua, Sinar Grafika, Jakarta, 2008

Hadari Nawawi, Metode Penelitian Bidang Sosial, Gajah Mada University Press, Yogyakarta, 1983

Moeljatno, Kitab Undang-undang Hukum Pidana [Wetboek van Straftrecht], Pradnya Paramita, Jakarta, 1976.

Steven Greer, The Margin of Appreciation: Interpretation and Discretion Under The European Convention On Human Rights, Council of Europe, United Kingdom, 2000.

Soerjono Soekanto, Penelitian Hukum Normatif, PT. Raja Grapindo Persada, Jakarta, 2004

Kitab Undang-Undang Hukum Pidana

Yulia A. Timofeeva, "Hate Speech Online: Restricted or Protected? Comparison of Regulations In The United States and Germany”, Journal Transnational \& Policy Vol. 12:2 Spring, 2003

\section{Peraturan Perundang-undangan}

Undang-Undang Dasar 1945 Amandemen Keempat. 2002.

Undang-Undang Nomor 11 Tahun 2008 tentang Informasi dan Transaksi Elektronik

Undang-Undang Nomor 40 Tahun 2008 tentang Penghapusan Diskriminasi Ras dan Etnis

Undang-Undang No. 39 Tahun 1999 Tentang Hak Asasi Manusia.

Surat Edaran Kepala Kepolisian Negara Republik Indonesia Nomor SE/6/X/2015 tentang Penanganan Ujaran Kebencian

\section{Peraturan Asing}

United Nations, Universal Declaration of Human Rights, 1948

United States, First Amandment of United States Constitution.

United States, International Covenant on Civil and Political Rights, 1976.

\section{Website}

Ruli, Surat Edaran Kapolri “Ujaran Kebencian” Dinilai Suatu Kemajuan” Dinilai Suatu Kemajuan, http://nasional.harianterbit.com /nasional/2015/10/29/45932//25/Surat-EdaranKapolri-Ujaran-Kebencian-Dinilai Suatu-Kemajuan, diunduh 23 Januari 2018. http://koran-sindo.com/page/news/2017-12-09/0/2/4 Kasus Hate Speech Di Indonesia , diakses pada 19 Mei 2018 pukul 15.54 